\title{
Dietary factors associated with wheezing and allergic rhinitis in children
}

\author{
S. Farchi*, F. Forastiere ${ }^{\#}$, N. Agabiti*, G. Corbo", R. Pistelli", C. Fortes ${ }^{+}$, V. Dell'Orco ${ }^{\S}$, C.A. Perucci\#
}

Dietary factors associated with wheezing and allergic rhinitis in children. S. Farchi, F. Forastiere, N. Agabiti, G. Corbo, R. Pistelli, C. Fortes, V. Dell'Orco, C.A. Perucci. (C) ERS Journals Ltd 2003.

ABSTRACT: The effect of dietary factors on asthma is controversial. This study examined food consumption and the use of fats in relation to wheezing and allergic rhinitis in children.

Baseline questionnaire data on individual and family characteristics were recorded by parents of 5,257 children aged 6-7 yrs living in central Italy participating in the International Study on Asthma and Allergies in Childhood study. A total of 4,104 children $(\mathbf{7 8 . 1} \%)$ were reinvestigated after $1 \mathrm{yr}$ using a second parental questionnaire to record occurrence of respiratory symptoms over the intervening 12 months. Consumption of foods rich in antioxidants, such as vitamins $\mathrm{C}$ and $\mathbf{E}$, animal fats, and food containing omega-3 fatty acids were investigated using a food-frequency questionnaire. Frequency of use of fats was also evaluated. Wheezing, shortness of breath with wheeze, and symptoms of allergic rhinitis in the past 12 months were considered.

Intake of cooked vegetables, tomatoes, and fruit were protective factors for any wheeze in the last 12 months and shortness of breath with wheeze. Consumption of citrus fruit had a protective role for shortness of breath with wheeze. Consumption of bread and margarine was associated with an increased risk of wheeze, while bread and butter was associated with shortness of breath with wheeze.

Dietary antioxidants in vegetables may reduce wheezing symptoms in childhood, whereas both butter and margarine may increase the occurrence of such symptoms. Eur Respir J 2003; 22: 772-780.

\begin{abstract}
*Agency for Public Health, Lazio Region, \#Dept of Epidemiology, Rome E Local Health Authority, "Dept of Respiratory Physiology, Catholic University, ${ }^{+}$Dept of Clinical Epidemiology, Dermatological Institute, Rome, and ${ }^{\S}$ Dept of Prevention, Rome G Local Health Authority, Colleferro, Italy.
\end{abstract}

Correspondence: F. Forastiere, Dept of Epidemiology, Rome E Local Health Authority, Via Santa Costanza 53, 00198 Roma, Italy. Fax: 390683060463

E-mail: epiamb1@asplazio.it

Keywords: Allergic rhinitis

asthma

childhood

diet

vitamin C

wheeze

Received: January 172003

Accepted after revision: May 282003
An increase in the prevalence of asthma over the last decades has been seen in developed countries [1-4]. The marked changes in the western diet, with decreased consumption of fresh fruit, vegetables, fish and milk, and the increased intake of foods rich in fats, have led to the hypothesis that the epidemiological changes of asthma are associated with the changes in food consumption [5-7]. Three main hypotheses on the effect of diet on asthma have been formulated, including excess in sodium intake [5], deficiency in dietary antioxidants [8], and changes in dietary balance between omega-3 polyunsaturated fatty acid (PUFA) (fish oil, fish and shellfish, and leafy vegetables), and omega-6 PUFA (vegetable fat, such as margarine and processed foods) [9]. The sodium hypothesis has been well studied and its impact on the increase in asthma incidence remains controversial [10], whereas antioxidants and fatty acids are appealing, since they seem to influence the immunological and inflammatory responses that are of key importance in asthma [11-14]. Lack of beta-carotene, vitamin $\mathrm{C}$ and vitamin $\mathrm{E}$ may increase susceptibility to oxidant attack and airway inflammation [12], while dietary fats may have negative effects on immune and inflammatory responses [13]. More recently, other nutrients have come into focus, such as magnesium intake [15], saturated fats [13], and other antioxidants, like selenium and consumption of flavonoid-rich foods and drinks [16].

Few studies have investigated the role of diet on childhood

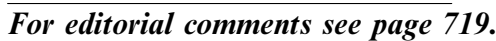

asthma, and the available investigations, with only one exception [17], have considered only individual food groups $[14,18-21]$. To evaluate the association of several dietary factors to wheeze and allergic rhinitis, the current study examined data collected in a large study performed on children living in two areas of central Italy.

\section{Methods}

The Italian Studies on Respiratory Disorders in Children and the Environment (SIDRIA) study was conducted in Italy between October 1994 and March 1995, as a part of the International Study on Asthma and Allergies in Childhood (ISAAC) initiative [1]. The survey was designed to estimate the prevalence of asthma and other atopic diseases in children and to investigate the potential risk factors for asthma. The study was conducted among children aged 6-7 yrs attending primary school, in eight centres of northern and central Italy. A detailed description of the methods of the study has been reported elsewhere $[4,22]$. The parents had to complete the Italian version of the ISAAC questionnaires at home. It included questions on a number of risk factors for childhood asthma and other respiratory and allergic diseases. Sociodemographical variables, such as parental education, household crowding, maternal and paternal smoking, presence of dampness and/or mould in the child's bedroom, and parental asthma, were collected. 
A follow-up study, $1 \mathrm{yr}$ after the first data collection, was conducted in two of the participating centres (Rome and Viterbo, a small town $\sim 80 \mathrm{~km}$ from Rome); the methods have already been described by the authors in a previous paper on fresh fruit consumption and wheezing [20]. A new questionnaire was sent to the parents of 5,257 children to record information on respiratory symptoms, including shortness of breath with wheezing, over the previous 12 months. In addition, parents filled in a detailed semiquantitative food frequency questionnaire. A total of 18 food items were investigated to study foods rich in antioxidants, such as carotenoids and vitamins $\mathrm{C}$ and $\mathrm{E}$ (cooked vegetables, salads, tomatoes, peppers, potatoes, fresh fruit, citrus fruit, kiwi, nuts), animal fats (bread and butter, milk, cheese, liver), vegetable fats (margarine, olives), and food containing omega-3 fatty acids (blue fish). The questionnaire assessed weekly consumption using a five-level scale: never, less than once a week, 1-2 times per week, 3-4 times per week, 5-7 times per week. Fresh tomatoes are important sources of vitamins and antioxidants but production and consumption are different by season. The loss of vitamins that occurs in storage and processing during the winter [23, 24], led the authors to study the consumption of both in season (summer) and out of season tomatoes. The questionnaire also contained questions about the frequency of use of fats for cooking, dressing, and sauces, asking whether butter, margarine, olive oil, and seeds oil were used never, sometimes, often, or always. Sauces with butter or margarine in Italy are usually eaten with pasta or rice.

In the present analysis, any wheezing in the past 12 months, the occurrence of attacks of shortness of breath with wheeze in the past 12 months, and the occurrence of symptoms related to allergic rhinitis (sneezing, or a runny/blocked nose apart from common cold/flu with itchy watery eyes) were the three outcome variables to be evaluated in relation to diet. Other respiratory symptoms (nocturnal dry cough and chronic cough apart from colds) were also evaluated, but for the sake of simplicity the authors decided to report in detail only those symptoms chosen a priori. Logistic regression was performed to analyse the association between food consumption (in five levels, using "never" as reference) or fats used for cooking, dressings and sauces ("never" was the reference) and the outcome variables, after adjusting for the following confounders: sex, study area, paternal education, household crowding, maternal smoking, paternal smoking, dampness or mould in the child's room, and parental asthma. When a specified category of food consumption had only few subjects $(\sim \leqslant 1 \%)$, it was combined with the category of lower consumption. Odds Ratio (OR) and 95\% confidence interval (95\% CI) were computed to estimate the degree of association. Moreover, food consumption was included as an ordinal variable in the logistic model to test for linear trend (Wald test). Spearman's correlation coefficients were computed to evaluate the degree of correlation among dietary variables.

\section{Results}

The response rate to the study was $78.1 \%$ for a total of 4,104 children. The response rate was higher in Viterbo $(85.9 \%)$ than in Rome $(75.7 \%)$ and it did not vary by sex, rate of parental asthma, or father's education. The characteristics of the children who participated in the study are shown in table 1 . Among the 4,104 children, almost 75\% lived in Rome, $37 \%$ were exposed to maternal smoking and $46 \%$ were exposed to paternal smoking. Occurrence of any wheeze, shortness of breath with wheeze, and rhinitis symptoms in the past 12 months were $5.8 \%, 3.8 \%$ and $8.5 \%$, respectively.

Tables 2 and 3 present the weekly consumption of the 18
Table 1.-Characteristics of the study subjects

Variable

Sex

Males

Females

$2103(51.3)$

Area of residence

Urban

Rural

$2001(48.7)$

Father's education

Primary school

Middle school

High school

University

Maternal smoking habits

Never

Exsmoker

Current smoker

Paternal smoking habits

Never

Exsmoker

$3047(74.3)$

1057 (25.7)

$412(10.0)$

$1504(36.6)$

$1468(35.7)$

605 (14.7)

$1738(42.3)$

$731(17.8)$

1505 (36.6)

$1127(27.4)$

Current smoker

930 (22.6)

1887 (45.9)

Dampness or mould in the bedroom

No

$3838(93.5)$

Yes

$185(4.5)$

Parental asthma

No

$3316(80.8)$

Yes

$691(16.8)$

Household crowding (inhabitants/room)

Low $(<1)$

Medium (1-2)

$634(15.4)$

$2731(66.5)$

High $(>2)$

$608(14.8)$

Any wheeze (past 12 months)

No

$3773(94.1)$

$233(5.8)$

Shortness of breath with wheeze (past 12 months)

No

$3864(96.1)$

Yes

$153(3.8)$

Allergic rhinitis (past 12 months)

No

$3753(91.5)$

Yes

$351(8.5)$

Nocturnal dry cough (past 12 months)

No

$3438(85.1)$

Yes

$601(14.9)$

Chronic cough (past 12 months)

No

$3605(89.2)$

Yes

$437(10.8)$

Data are presented as $\mathrm{n}(\%)$.

different food items and the use of fats for cooking, dressing, and sauces. The last column indicates the number of subjects for which information was available. A relatively frequent consumption of milk, tomatoes, and fresh fruit (in particular citrus fruit) and an infrequent use of animal fats (bread and butter, and bread and margarine, and cheese) were recorded. The rare use of bread and butter and bread and margarine is not a surprise given the traditional diet in central Italy. Olive oil was the principal fat used for cooking and dressing. When the matrix of Spearman's correlation coefficients was examined, there was a moderate correlation (maximum 0.50) among foods pertaining to the same food group (orange/kiwi, salad/tomatoes), while the correlation among the dietary variables pertaining to different food groups was low, with the highest values found for fruit and vegetables (0.30). The correlation between consumption of bread and butter and bread and margarine was also low (0.23).

Tables 4-9 report the adjusted OR and $95 \%$ CI of the association of wheeze, shortness of breath with wheeze, and allergic rhinitis during the last 12 months with 
Table 2.-Description of food consumption

\begin{tabular}{|c|c|c|c|c|c|c|}
\hline & \multicolumn{5}{|c|}{ Consumption per week } & \multirow[t]{2}{*}{ Total } \\
\hline & Never & $<1$ & $1-2$ & $3-4$ & $>4$ & \\
\hline Cooked vegetables & 11.5 & 15.0 & 29.5 & 22.4 & 21.6 & 3892 \\
\hline Fresh salads & 21.3 & 15.2 & 27.0 & 19.7 & 16.8 & 3901 \\
\hline Summer tomatoes & 15.4 & 10.5 & 28.1 & 25.6 & 20.4 & 3935 \\
\hline Out of season tomatoes & 38.7 & 24.8 & 24.1 & 7.3 & 5.1 & 3800 \\
\hline Peppers & 62.8 & 20.4 & 13.1 & 2.1 & 1.6 & 3823 \\
\hline Potatoes & 1.2 & 11.8 & 47.4 & 25.0 & 14.6 & 3907 \\
\hline Fresh fruit & 2.1 & 6.4 & 15.9 & 22.0 & 53.6 & 3915 \\
\hline Citrus fruit & 9.2 & 10.8 & 21.9 & 23.4 & 34.7 & 3897 \\
\hline Kiwi & 35.2 & 26.0 & 22.6 & 8.4 & 7.8 & 3870 \\
\hline $\begin{array}{l}\text { Nuts (walnuts, hazelnuts, } \\
\text { almonds, peanuts) }\end{array}$ & 37.2 & 43.7 & 13.8 & 2.8 & 2.5 & 3901 \\
\hline Olives & 28.6 & 41.1 & 23.0 & 4.6 & 2.7 & 3819 \\
\hline Bread and butter & 76.8 & 12.2 & 8.2 & 1.4 & 1.4 & 3804 \\
\hline Bread and margarine & 95.6 & 2.2 & 1.4 & 0.3 & 0.5 & 3696 \\
\hline Milk & 4.7 & 4.2 & 11.6 & 10.1 & 69.4 & 3920 \\
\hline Cheese & 6.4 & 11.7 & 39.5 & 28.0 & 14.4 & 3915 \\
\hline Liver & 76.4 & 17.0 & 6.0 & 0.4 & 0.2 & 3809 \\
\hline $\begin{array}{l}\text { Pasta with fish (tuna, } \\
\text { mackerel, sardines, } \\
\text { salmon, anchovies) }\end{array}$ & 23.9 & 37.5 & 35.9 & 1.8 & 0.9 & 3890 \\
\hline $\begin{array}{l}\text { Fish (tuna, mackerel, } \\
\text { sardines, salmon, } \\
\text { anchovies) }\end{array}$ & 17.4 & 29.0 & 50.5 & 2.7 & 0.4 & 3871 \\
\hline
\end{tabular}

Data are presented as $\%$, except total, which give the number of subjects with available information on the specific item.

the frequency of various foods intake and uses of fats. The p-value for trend evaluates the potential linear relationship with the outcome variables across the categories of food consumption.

A protective effect of fresh vegetables and fruit on wheeze (during the past 12 months) was observed (table 4). In particular, reduced wheezing corresponds to a higher intake of salads $(\mathrm{p}=0.047)$. The effect is even stronger for those consuming summer tomatoes; the OR for children who eat tomatoes more than four times per week in comparison with those who do not was 0.49 (95\% CI: $0.31-0.80, \mathrm{p}=0.003)$. A protective effect was also seen in children who frequently consume nuts $(\mathrm{p}=0.017)$. OR below one and indications of a trend were seen in the frequent intake of fresh fruit, citrus fruit, and kiwi.

A significantly higher prevalence of wheezing was noted

Table 3.-Description of use of fats in cooking, dressing, and sauces

\begin{tabular}{lrrrrr}
\hline & \multicolumn{3}{c}{ Consumption per week } & \multirow{2}{*}{ Total } \\
\cline { 2 - 4 } & Never & Sometimes & Often & Always & \\
\hline Fats for cooking & & & & & \\
$\quad$ Olive oil & 1.8 & 5.3 & 15.2 & 77.7 & 3938 \\
$\quad$ Seed oil & 24.6 & 59.7 & 9.9 & 5.8 & 3567 \\
$\quad$ Butter & 25.0 & 66.9 & 6.4 & 1.7 & 3538 \\
$\quad$ Margarine & 76.5 & 19.6 & 3.1 & 0.8 & 3407 \\
Fats for dressing & & & & & \\
$\quad \begin{array}{l}\text { Olive oil } \\
\text { Seed oil }\end{array}$ & 0.6 & 1.6 & 6.5 & 91.3 & 3971 \\
Fats for sauces & 86.2 & 10.7 & 1.8 & 1.3 & 3297 \\
$\quad$ Butter (usually pasta) & 51.3 & 44.4 & 3.2 & 1.1 & 3411 \\
$\quad \begin{array}{l}\text { Margarine (usually } \\
\quad \text { pasta) }\end{array}$ & 89.7 & 8.8 & 0.9 & 0.6 & 3297 \\
$\quad$ & & & & & \\
\hline
\end{tabular}

Data are presented as $\%$, except total, which give the number of subjects with available information on the specific item. among children who eat bread and margarine at least once per week in comparison with children who never eat bread this way $(\mathrm{OR}=2.52 ; 95 \% \mathrm{CI}$ : 1.25-5.09) (table 5). Butter used as a cooking fat was positively associated with wheeze $(\mathrm{p}=0.031)$. Moreover, those who usually use butter on pasta had an increased risk for wheeze $(\mathrm{OR}=2.85$; 95\% CI: 1.01-7.42).

Confirming the results for "any wheeze", summer tomatoes and fresh fruit, in particular citrus fruit, had a beneficial effect in preventing shortness of breath with wheeze (table 6). The OR of children who consume tomatoes, fresh fruit, and citrus fruit more than four times per week in comparison with those who do not eat these foods were 0.55 (95\% CI: 0.32-0.96), 0.37 (95\% CI: $0.16-0.85)$ and 0.59 (95\% CI: $0.35-1.00)$, respectively and $\mathrm{p}=0.031,0.022$, and 0.016 , respectively. Bread and butter consumed more than four times per week $(\mathrm{OR}=3.12$; 95\% CI: 1.18-8.23) was positively associated with shortness of breath with wheeze.

Only three associations were noteworthy for allergic rhinitis: consumption of nuts, milk intake, and butter in sauces (tables 8 and 9). Children with frequent consumption of nuts (more than four times per week) had a higher risk of rhinitis $(\mathrm{OR}=2.12,95 \% \mathrm{CI}=1.21-3.71)$. A significantly lower prevalence of nasal symptoms was noted among children who drink milk more than three times per week in comparison with children who never drank milk $(\mathrm{p}=0.011)$. Butter used for sauces was positively associated with frequency of rhinitis $(\mathrm{p}=0.047)$.

Table 10 summarises the main results of the associations between fruit and vegetables consumption and fats consumption with the two wheezing symptoms and also illustrates the findings for the same food items in relation with nocturnal dry cough and chronic cough. The OR of the comparisons between the highest versus the lowest consumption categories are reported, together with the results of the trend test across the consumption categories. The protective effects of cooked vegetables, summer tomatoes, fresh fruit, and citrus fruit were consistent for the four respiratory symptoms investigated. The negative effects of butter (with bread or for cooking) were present only for wheezing symptoms and not for cough symptoms whereas margarine (with bread) was more or less associated with all the four symptoms.

\section{Discussion}

The current study found a protective effect for vegetable and fresh fruit consumption and a negative effect for butter and margarine use on wheezing symptoms in children. Apart from butter, none of these foods were associated with allergic rhinitis. No effect for fish containing omega-3 fatty acids was found.

The present analysis confirms the protective role of citrus fruit on wheezing [20], and suggests associations with other dietary items. The protective effects seem to be clear for vegetables, in particular tomatoes, and fresh fruit. Both "any wheeze" and "shortness of breath with wheeze" decreased in relation to an increased consumption of summer tomatoes and fresh fruit. Vegetables and fruit are the major source of antioxidant vitamins, such as vitamin $\mathrm{C}$ and carotenoids. Dietary intake of these vitamins may exert an activity against oxidative lung damage and may decrease the inflammation of the airway [10]. It has been suggested that vitamin $C$ is the major antioxidant substance in the airways and it protects against endogenous and exogenous oxidant molecules [25]. Vitamin $C$ is the most abundant antioxidant substance in the extracellular fluid in the lung and contributes to the regeneration of membrane-bound oxidised vitamin $\mathrm{E}$, allowing it to 
Table 4. - Association between food consumption and 12 month occurrence of wheeze

\begin{tabular}{|c|c|c|c|c|c|c|}
\hline & \multicolumn{5}{|c|}{ Consumption per week } & \multirow{2}{*}{$\begin{array}{l}\mathrm{p} \text {-value } \\
\text { for trend }\end{array}$} \\
\hline & Never* & $<1$ & $1-2$ & $3-4$ & $>4$ & \\
\hline Cooked vegetables & 1.00 & $\begin{array}{c}0.82 \\
(0.49-1.35)\end{array}$ & $\begin{array}{c}0.85 \\
(0.55-1.33)\end{array}$ & $\begin{array}{c}0.78 \\
(0.49-1.25)\end{array}$ & $\begin{array}{c}0.67 \\
(0.41-1.09)\end{array}$ & 0.125 \\
\hline Fresh salads & 1.00 & $\begin{array}{c}0.93 \\
(0.61-1.43)\end{array}$ & $\begin{array}{c}0.76 \\
(0.52-1.12)\end{array}$ & $\begin{array}{c}0.77 \\
(0.51-1.17)\end{array}$ & $\begin{array}{c}0.66 \\
(0.41-1.04)\end{array}$ & 0.047 \\
\hline Summer tomatoes & 1.00 & $\begin{array}{c}0.90 \\
(0.55-1.48)\end{array}$ & $\begin{array}{c}0.79 \\
(0.53-1.18)\end{array}$ & $\begin{array}{c}0.71 \\
(0.47-1.08)\end{array}$ & $\begin{array}{c}0.49 \\
(0.31-0.80)\end{array}$ & 0.003 \\
\hline Out of season tomatoes & 1.00 & $\begin{array}{c}0.89 \\
(0.62-1.27)\end{array}$ & $\begin{array}{c}0.69 \\
(0.47-1.00)\end{array}$ & $\begin{array}{c}0.97 \\
(0.57-1.66)\end{array}$ & $\begin{array}{c}0.73 \\
(0.37-1.45)\end{array}$ & 0.167 \\
\hline Peppers & 1.00 & $\begin{array}{c}1.11 \\
(0.79-1.56)\end{array}$ & $\begin{array}{c}0.91 \\
(0.59-1.41)\end{array}$ & $\begin{array}{c}0.38 \\
(0.09-1.60)\end{array}$ & $\begin{array}{c}0.88 \\
(0.27-2.89)\end{array}$ & 0.455 \\
\hline Potatoes & 1.00 & $\begin{array}{c}0.85 \\
(0.28-2.60)\end{array}$ & $\begin{array}{c}0.62 \\
(0.21-1.82)\end{array}$ & $\begin{array}{c}0.72 \\
(0.24-2.12)\end{array}$ & $\begin{array}{c}0.63 \\
(0.21-1.91)\end{array}$ & 0.451 \\
\hline Fruit & 1.00 & $\begin{array}{c}0.61 \\
(0.24-1.53)\end{array}$ & $\begin{array}{c}0.63 \\
(0.28-1.43)\end{array}$ & $\begin{array}{c}0.59 \\
(0.26-1.31)\end{array}$ & $\begin{array}{c}0.51 \\
(0.24-1.11)\end{array}$ & 0.090 \\
\hline Citrus fruit & 1.00 & $\begin{array}{c}0.86 \\
(0.47-1.55)\end{array}$ & $\begin{array}{c}0.82 \\
(0.49-1.36)\end{array}$ & $\begin{array}{c}0.51 \\
(0.30-0.87)\end{array}$ & $\begin{array}{c}0.93 \\
(0.58-1.49)\end{array}$ & 0.700 \\
\hline Kiwi & 1.00 & $\begin{array}{c}0.67 \\
(0.46-0.96)\end{array}$ & $\begin{array}{c}0.69 \\
(0.48-1.01)\end{array}$ & $\begin{array}{c}0.81 \\
(0.48-1.36)\end{array}$ & $\begin{array}{c}0.67 \\
(0.37-1.20)\end{array}$ & 0.085 \\
\hline Nuts & 1.00 & $\begin{array}{c}0.86 \\
(0.64-1.71)\end{array}$ & $\begin{array}{c}0.69 \\
(0.43-1.10)\end{array}$ & $\begin{array}{c}0.85 \\
(0.37-1.93)\end{array}$ & $\begin{array}{c}0.13 \\
(0.02-0.95)\end{array}$ & 0.017 \\
\hline Olives & 1.00 & $\begin{array}{c}0.62 \\
(0.44-0.87)\end{array}$ & $\begin{array}{c}0.85 \\
(0.59-1.23)\end{array}$ & $\begin{array}{c}0.47 \\
(0.20-1.11)\end{array}$ & $\begin{array}{c}1.53 \\
(0.74-3.15)\end{array}$ & 0.697 \\
\hline Bread and butter & 1.00 & $\begin{array}{c}1.20 \\
(0.79-1.81)\end{array}$ & $\begin{array}{c}1.04 \\
(0.62-1.73)\end{array}$ & $\begin{array}{c}1.64 \\
(0.57-4.72)\end{array}$ & $\begin{array}{c}2.09 \\
(0.80-5.44)\end{array}$ & 0.143 \\
\hline Bread and margarine & 1.00 & $\begin{array}{c}0.88 \\
(0.31-2.48)\end{array}$ & $\begin{array}{c}2.52 \\
(1.25-5.09)\end{array}$ & & & 0.024 \\
\hline Milk & 1.00 & $\begin{array}{c}0.88 \\
(0.35-2.1)\end{array}$ & $\begin{array}{c}1.20 \\
(0.59-2.48)\end{array}$ & $\begin{array}{c}1.15 \\
(0.55-2.40)\end{array}$ & $\begin{array}{c}0.90 \\
(0.47-1.71)\end{array}$ & 0.353 \\
\hline Cheese & 1.00 & $\begin{array}{c}0.71 \\
(0.38-1.32)\end{array}$ & $\begin{array}{c}0.70 \\
(0.42-1.72)\end{array}$ & $\begin{array}{c}0.70 \\
(0.41-1.20)\end{array}$ & $\begin{array}{c}0.86 \\
(0.49-1.52)\end{array}$ & 0.862 \\
\hline Liver & 1.00 & $\begin{array}{c}0.85 \\
(0.58-1.25)\end{array}$ & $\begin{array}{c}0.79 \\
(0.43-1.46)\end{array}$ & & & 0.304 \\
\hline Pasta with fish & 1.00 & $\begin{array}{c}1.01 \\
(0.71-1.44)\end{array}$ & $\begin{array}{c}0.87 \\
(0.61-1.26)\end{array}$ & $\begin{array}{c}0.96 \\
(0.39-2.32)\end{array}$ & & 0.474 \\
\hline Fish & 1.00 & $\begin{array}{c}0.66 \\
(0.44-0.99)\end{array}$ & $\begin{array}{c}0.86 \\
(0.61-1.23)\end{array}$ & $\begin{array}{c}0.77 \\
(0.32-1.86)\end{array}$ & & 0.743 \\
\hline
\end{tabular}

Data are presented as odds ratio (OR) $(95 \%$ confidence interval). OR are adjusted for the following confounders: sex, study area, paternal education, maternal and paternal smoking, parental asthma, dampness or mould in the child's room, household crowding. When a specific category of food intake had $<1 \%$ of the subject, the category has been merged with the preceding category. *: reference.

Table 5.-Association between use of fats in cooking, dressing and sauces and 12 month occurrence of wheeze

\begin{tabular}{|c|c|c|c|c|c|}
\hline & \multicolumn{4}{|c|}{ Consumption per week } & \multirow[t]{2}{*}{$\mathrm{p}$-value for trend } \\
\hline & Never* & Sometimes & Often & Always & \\
\hline \multicolumn{6}{|c|}{ Fats for cooking } \\
\hline Olive oil & 1.00 & $0.70(0.23-2.17)$ & $1.00(0.37-2.67)$ & $0.90(0.35-2.30)$ & 0.928 \\
\hline Seed oil & 1.00 & $\begin{array}{c}1.20(0.83-1.72) \\
11\end{array}$ & $1.30(0.76-2.21)$ & $0.88(0.43-1.79)$ & 0.826 \\
\hline Butter & 1.00 & $1.08(0.76-1.53)$ & $1.79(1.02-3.15)$ & $2.19(0.90-5.30)$ & 0.031 \\
\hline Margarine & 1.00 & $1.30(0.91-1.85)$ & $1.38(0.72-2.67)$ & & 0.107 \\
\hline \multicolumn{6}{|c|}{ Fats for dressing } \\
\hline Olive oil & & 1.00 & $1.28(0.40-4.05)$ & $1.32(0.47-3.73)$ & 0.636 \\
\hline Seed oil & 1.00 & $0.86(0.52-1.41)$ & $0.75(0.22-2.50)$ & $0.81(0.24-2.78)$ & 0.465 \\
\hline \multicolumn{6}{|l|}{ Fats for sauces } \\
\hline Butter & 1.00 & $0.84(0.62-1.14)$ & 0.88 & $2.85(1.01-7.42)$ & 0.892 \\
\hline Margarine & 1.00 & $1.40(0.87-2.23)$ & $1.25(0.80-1.97)$ & & 0.327 \\
\hline
\end{tabular}

Data are presented as odds ratio (OR) $(95 \%$ confidence interval). OR are adjusted for the following confounders: sex, study area, paternal education, maternal and paternal smoking, parental asthma, dampness or mould in the child's room, household crowding. When a specific category of food intake had $<1 \%$ of the subject, the category has been merged with the preceding or following category. *: reference. 
Table 6. - Association between food consumption and 12 month occurrence of shortness of breath with wheeze

\begin{tabular}{|c|c|c|c|c|c|c|}
\hline & \multicolumn{5}{|c|}{ Consumption per week } & \multirow[t]{2}{*}{$\mathrm{p}$-value for trend } \\
\hline & Never* & $<1$ & $1-2$ & $3-4$ & $>4$ & \\
\hline Cooked vegetables & 1.00 & $\begin{array}{c}0.68 \\
(0.37-1.24)\end{array}$ & $\begin{array}{c}0.63 \\
(0.37-1.06)\end{array}$ & $\begin{array}{c}0.62 \\
(0.35-1.08)\end{array}$ & $\begin{array}{c}0.72 \\
(0.41-1.25)\end{array}$ & 0.318 \\
\hline Fresh salads & 1.00 & $\begin{array}{c}0.76 \\
(0.43-1.34)\end{array}$ & $\begin{array}{c}0.91 \\
(0.57-1.46)\end{array}$ & $\begin{array}{c}0.79 \\
(0.46-1.33)\end{array}$ & $\begin{array}{c}0.98 \\
(0.58-1.65)\end{array}$ & 0.871 \\
\hline Summer tomatoes & 1.00 & $\begin{array}{c}0.70 \\
(0.38-1.30)\end{array}$ & $\begin{array}{c}0.73 \\
(0.46-1.17)\end{array}$ & $\begin{array}{c}0.63 \\
(0.38-1.04)\end{array}$ & $\begin{array}{c}0.55 \\
(0.32-0.96)\end{array}$ & 0.031 \\
\hline Out of season tomatoes & 1.00 & $\begin{array}{c}0.97 \\
(0.63-1.49)\end{array}$ & $\begin{array}{c}0.68 \\
(0.42-1.09)\end{array}$ & $\begin{array}{c}1.44 \\
(0.80-2.57)\end{array}$ & $\begin{array}{c}1.12 \\
(0.54-2.3)\end{array}$ & 0.901 \\
\hline Peppers & 1.00 & $\begin{array}{c}1.12 \\
(0.74-1.68)\end{array}$ & $\begin{array}{c}0.90 \\
(0.52-1.54)\end{array}$ & $\begin{array}{c}0.30 \\
(0.04-2.20)\end{array}$ & $\begin{array}{c}1.81 \\
(0.63-5.21)\end{array}$ & 0.951 \\
\hline Potatoes & 1.00 & $\begin{array}{c}0.90 \\
(0.25-3.21)\end{array}$ & $\begin{array}{c}0.53 \\
(0.15-1.81)\end{array}$ & $\begin{array}{c}0.58 \\
(0.17-2.02)\end{array}$ & $\begin{array}{c}0.76 \\
(0.21-2.70)\end{array}$ & 0.825 \\
\hline Fruit & 1.00 & $\begin{array}{c}0.59 \\
(0.22-1.57)\end{array}$ & $\begin{array}{c}0.46 \\
(0.19-1.11)\end{array}$ & $\begin{array}{c}0.37 \\
(0.15-0.89)\end{array}$ & $\begin{array}{c}0.37 \\
(0.16-0.85)\end{array}$ & 0.022 \\
\hline Citrus fruit & 1.00 & $\begin{array}{c}0.73 \\
(0.38-1.40)\end{array}$ & $\begin{array}{c}0.65 \\
(0.37-1.13)\end{array}$ & $\begin{array}{c}0.26 \\
(0.14-0.51)\end{array}$ & $\begin{array}{c}0.59 \\
(0.35-1.00)\end{array}$ & 0.016 \\
\hline Kiwi & 1.00 & $\begin{array}{c}0.67 \\
(0.43-1.04)\end{array}$ & $\begin{array}{c}0.57 \\
(0.35-0.93)\end{array}$ & $\begin{array}{c}0.81 \\
(0.43-1.54)\end{array}$ & $\begin{array}{c}1.07 \\
(0.58-1.96)\end{array}$ & 0.467 \\
\hline Nuts & 1.00 & $\begin{array}{c}0.69 \\
(0.47-1.00)\end{array}$ & $\begin{array}{c}0.59 \\
(0.33-1.06)\end{array}$ & $\begin{array}{c}1.89 \\
(0.89-4.03)\end{array}$ & $\begin{array}{c}0.38 \\
(0.08-1.62)\end{array}$ & 0.239 \\
\hline Olives & 1.00 & $\begin{array}{c}0.60 \\
(0.40-0.89)\end{array}$ & $\begin{array}{c}0.76 \\
(0.49-1.20)\end{array}$ & $\begin{array}{c}0.76 \\
(0.33-1.74)\end{array}$ & $\begin{array}{c}1.28 \\
(0.52-3.14)\end{array}$ & 0.637 \\
\hline Bread and butter & 1.00 & $\begin{array}{c}1.13 \\
(0.68-1.87)\end{array}$ & $\begin{array}{c}0.77 \\
(0.38-1.56)\end{array}$ & $\begin{array}{c}2.53 \\
(0.87-7.38)\end{array}$ & $\begin{array}{c}3.12 \\
(1.18-8.23)\end{array}$ & 0.106 \\
\hline Bread and margarine & 1.00 & $\begin{array}{c}1.38 \\
(0.46-3.66)\end{array}$ & $\begin{array}{c}1.90 \\
(0.74-4.89)\end{array}$ & & & 0.164 \\
\hline Milk & 1.00 & $\begin{array}{c}1.45 \\
(0.48-4.36)\end{array}$ & $\begin{array}{c}0.94 \\
(0.35-2.50)\end{array}$ & $\begin{array}{c}1.14 \\
(0.43-3.02)\end{array}$ & $\begin{array}{c}1.08 \\
(0.46-2.52)\end{array}$ & 0.975 \\
\hline Cheese & 1.00 & $\begin{array}{c}0.74 \\
(0.37-1.48)\end{array}$ & $\begin{array}{c}0.56 \\
(0.31-1.01)\end{array}$ & $\begin{array}{c}0.56 \\
(0.30-1.04)\end{array}$ & $\begin{array}{c}0.72 \\
(0.37-1.39)\end{array}$ & 0.326 \\
\hline Liver & 1.00 & $\begin{array}{c}1.14 \\
(0.74-1.75)\end{array}$ & $\begin{array}{c}1.04 \\
(0.53-2.04)\end{array}$ & & & 0.684 \\
\hline Pasta with fish & 1.00 & $\begin{array}{c}1.00 \\
(0.66-1.52)\end{array}$ & $\begin{array}{c}0.77 \\
(0.49-1.20)\end{array}$ & $\begin{array}{c}0.86 \\
(0.29-2.53)\end{array}$ & & 0.237 \\
\hline Fish & 1.00 & $\begin{array}{c}0.84 \\
(0.52-1.35)\end{array}$ & $\begin{array}{c}0.77 \\
(0.50-1.19)\end{array}$ & $\begin{array}{c}0.97 \\
(0.36-2.58)\end{array}$ & & 0.343 \\
\hline
\end{tabular}

Data are presented as odds ratio (OR) $(95 \%$ confidence interval). OR are adjusted for the following confounders: sex, study area, paternal education, maternal and paternal smoking, parental asthma, dampness or mould in the child's room, household crowding. When a specific category of food intake had $<1 \%$ of the subject, the category has been merged with the preceding category. *: reference.

Table 7.-Association between use of fats in cooking, dressing and sauces and 12 month occurrence of shortness of breath and wheeze

\begin{tabular}{|c|c|c|c|c|c|}
\hline & \multicolumn{4}{|c|}{ Consumption per week } & \multirow[t]{2}{*}{$\mathrm{p}$-value for trend } \\
\hline & Never* & Sometimes & Often & Always & \\
\hline \multicolumn{6}{|c|}{ Fats for cooking } \\
\hline Olive oil & 1.00 & $0.52(0.14-1.95)$ & $0.77(0.25-2.31)$ & $0.68(0.24-1.92)$ & 0.761 \\
\hline Seed oil & 1.00 & $0.90(0.59-1.37)$ & $0.90(0.47-1.73)$ & $1.02(0.48-2.17)$ & 0.912 \\
\hline Butter & 1.00 & $0.94(0.62-1.41)$ & $1.33(0.67-2.66)$ & $1.52(0.50-4.60)$ & 0.472 \\
\hline Margarine & 1.00 & $1.10(0.71-1.69)$ & $1.40(0.66-3.00)$ & & 0.384 \\
\hline \multicolumn{6}{|c|}{ Fats for dressing } \\
\hline Olive oil & & 1.00 & $1.25(0.344 .63)$ & $0.98(0.30-3.21)$ & 0.601 \\
\hline Seed oil & 1.00 & $0.94(0.52-1.69)$ & $1.73(0.59-5.02)$ & $0.95(0.22-4.15)$ & 0.757 \\
\hline \multicolumn{6}{|l|}{ Fats for sauces } \\
\hline Butter & 1.00 & $0.91(0.63-1.31)$ & $1.16(0.45-2.98)$ & $1.76(0.50-6.15)$ & 0.829 \\
\hline Margarine & 1.00 & $1.16(0.63-2.11)$ & $1.21(0.70-2.10)$ & & 0.499 \\
\hline
\end{tabular}

Data are presented as odds ratio (OR) (95\% confidence interval). OR are adjusted for the following confounders: sex, study area, paternal education, maternal and paternal smoking, parental asthma, dampness or mould in the child's room, household crowding. When a specific category of food intake had $<1 \%$ of the subject, the category has been merged with the preceding or following category. *: reference. 
Table 8. - Association between food consumption and 12 month occurrence of allergic rhinitis

\begin{tabular}{|c|c|c|c|c|c|c|}
\hline & \multicolumn{5}{|c|}{ Consumption per week } & \multirow[t]{2}{*}{$\mathrm{p}$-value for trend } \\
\hline & Never* & $<1$ & $1-2$ & $3-4$ & $>4$ & \\
\hline Cooked vegetables & 1.00 & $\begin{array}{c}0.84 \\
(0.55-1.27)\end{array}$ & $\begin{array}{c}0.76 \\
(0.52-1.10)\end{array}$ & $\begin{array}{c}0.75 \\
(0.51-1.12)\end{array}$ & $\begin{array}{c}0.88 \\
(0.59-1.30)\end{array}$ & 0.567 \\
\hline Fresh salads & 1.00 & $\begin{array}{c}1.05 \\
(0.74-1.49)\end{array}$ & $\begin{array}{c}0.67 \\
(0.48-0.94)\end{array}$ & $\begin{array}{c}0.80 \\
(0.57-1.14)\end{array}$ & $\begin{array}{c}0.87 \\
(0.61-1.24)\end{array}$ & 0.152 \\
\hline Summer tomatoes & 1.00 & $\begin{array}{c}1.14 \\
(0.75-1.72)\end{array}$ & $\begin{array}{c}0.76 \\
(0.53-1.08)\end{array}$ & $\begin{array}{c}0.82 \\
(0.57-1.17)\end{array}$ & $\begin{array}{c}0.96 \\
(0.56-1.38)\end{array}$ & 0.456 \\
\hline Out of season tomatoes & 1.00 & $\begin{array}{c}1.00 \\
(0.75-1.35)\end{array}$ & $\begin{array}{c}1.06 \\
(0.79-1.43)\end{array}$ & $\begin{array}{c}1.28 \\
(0.83-1.97)\end{array}$ & $\begin{array}{c}1.02 \\
(0.61-1.73)\end{array}$ & 0.450 \\
\hline Peppers & 1.00 & $\begin{array}{c}0.76 \\
(0.56-1.03)\end{array}$ & $\begin{array}{c}0.78 \\
(0.54-1.12)\end{array}$ & $\begin{array}{c}1.22 \\
(0.61-2.41)\end{array}$ & $\begin{array}{c}0.97 \\
(0.41-2.30)\end{array}$ & 0.317 \\
\hline Potatoes & 1.00 & $\begin{array}{c}1.18 \\
(0.40-3.45)\end{array}$ & $\begin{array}{c}0.85 \\
(0.30-2.43)\end{array}$ & $\begin{array}{c}1.31 \\
(0.46-3.74)\end{array}$ & $\begin{array}{c}1.21 \\
(0.42-3.51)\end{array}$ & 0.088 \\
\hline Fruit & 1.00 & $\begin{array}{c}0.43 \\
(0.19-0.94)\end{array}$ & $\begin{array}{c}0.45 \\
(0.23-0.90)\end{array}$ & $\begin{array}{c}0.60 \\
(0.31-1.16)\end{array}$ & $\begin{array}{c}0.56 \\
(0.30-1.05)\end{array}$ & 0.776 \\
\hline Citrus fruit & 1.00 & $\begin{array}{c}1.09 \\
(0.66-1.79)\end{array}$ & $\begin{array}{c}1.02 \\
(0.66-1.59)\end{array}$ & $\begin{array}{c}1.01 \\
(0.65-1.57)\end{array}$ & $\begin{array}{c}1.00 \\
(0.66-1.52)\end{array}$ & 0.830 \\
\hline Kiwi & 1.00 & $\begin{array}{c}0.94 \\
(0.71-1.26)\end{array}$ & $\begin{array}{c}0.83 \\
(0.61-1.13)\end{array}$ & $\begin{array}{c}0.62 \\
(0.37-1.02)\end{array}$ & $\begin{array}{c}1.28 \\
(0.85-1.91)\end{array}$ & 0.734 \\
\hline Nuts & 1.00 & $\begin{array}{c}0.82 \\
(0.63-1.06)\end{array}$ & $\begin{array}{c}0.97 \\
(0.69-1.38)\end{array}$ & $\begin{array}{c}1.27 \\
(0.69-2.35)\end{array}$ & $\begin{array}{c}2.12 \\
(1.21-3.71)\end{array}$ & 0.093 \\
\hline Olives & 1.00 & $\begin{array}{c}1.04 \\
(0.79-1.38)\end{array}$ & $\begin{array}{c}0.94 \\
(0.68-1.31)\end{array}$ & $\begin{array}{c}1.15 \\
(0.67-1.97)\end{array}$ & $\begin{array}{c}2.34 \\
(1.33-4.13)\end{array}$ & 0.121 \\
\hline Bread and butter & 1.00 & $\begin{array}{c}0.72 \\
(0.49-1.07)\end{array}$ & $\begin{array}{c}0.98 \\
(0.65-1.48)\end{array}$ & $\begin{array}{c}1.10 \\
(0.43-2.80)\end{array}$ & $\begin{array}{c}1.79 \\
(0.83-3.89)\end{array}$ & 0.703 \\
\hline Bread and margarine & 1.00 & $\begin{array}{c}1.30 \\
(0.64-2.65)\end{array}$ & $\begin{array}{c}1.11 \\
(0.53-2.35)\end{array}$ & & & 0.571 \\
\hline Milk & 1.00 & $\begin{array}{c}1.11 \\
(0.59-2.08)\end{array}$ & $\begin{array}{c}0.62 \\
(0.36-1.09)\end{array}$ & $\begin{array}{c}0.56 \\
(0.31-0.99)\end{array}$ & $\begin{array}{c}0.61 \\
(0.38-0.96)\end{array}$ & 0.011 \\
\hline Cheese & 1.00 & $\begin{array}{c}0.77 \\
(0.46-1.28)\end{array}$ & $\begin{array}{c}0.77 \\
(0.50-1.19)\end{array}$ & $\begin{array}{c}0.74 \\
(0.47-1.16)\end{array}$ & $\begin{array}{c}0.85 \\
(0.52-1.39)\end{array}$ & 0.677 \\
\hline Liver & 1.00 & $\begin{array}{c}1.02 \\
(0.75-1.37)\end{array}$ & $\begin{array}{c}1.08 \\
(0.70-1.68)\end{array}$ & & & 0.729 \\
\hline Pasta with fish & 1.00 & $\begin{array}{c}0.80 \\
(0.60-1.06)\end{array}$ & $\begin{array}{c}0.75 \\
(0.56-1.00)\end{array}$ & $\begin{array}{c}1.38 \\
(0.76-2.50)\end{array}$ & & 0.306 \\
\hline Fish & 1.00 & $\begin{array}{c}0.81 \\
(0.58-1.12)\end{array}$ & $\begin{array}{c}0.82 \\
(0.61-1.11)\end{array}$ & $\begin{array}{c}1.12 \\
(0.60-2.11)\end{array}$ & & 0.503 \\
\hline
\end{tabular}

Data are presented as odds ratio (OR) (95\% confidence interval). OR are adjusted for the following confounders: sex, study area, paternal education, maternal and paternal smoking, parental asthma, dampness or mould in the child's room, household crowding. When a specific category of food intake had $<1 \%$ of the subject, the category has been merged with the preceding or following category. *: reference.

Table 9.-Association between use of fats in cooking, dressing and sauces and 12 month occurrence of allergic rhinitis

\begin{tabular}{|c|c|c|c|c|c|}
\hline & \multicolumn{4}{|c|}{ Consumption per week } & \multirow[t]{2}{*}{$\mathrm{p}$-value for trend } \\
\hline & Never* & Sometimes & Often & Always & \\
\hline \multicolumn{6}{|c|}{ Fats for cooking } \\
\hline Olive oil & 1.00 & $1.19(0.48-2.93)$ & $1.06(0.46-2.43)$ & $0.87(0.39-1.94)$ & 0.121 \\
\hline Seed oil & 1.00 & $1.14(0.85-1.53)$ & $1.61(1.07-2.44)$ & $1.21(0.71-2.07)$ & 0.097 \\
\hline Butter & 1.00 & $0.97(0.73-1.28)$ & $1.68(1.07-2.63)$ & $1.42(0.64-3.13)$ & 0.101 \\
\hline Margarine & 1.00 & $0.93(0.68-1.26)$ & $1.20(0.68-1.26)$ & & 0.918 \\
\hline \multicolumn{6}{|c|}{ Fats for dressing } \\
\hline Olive oil & & 1.00 & $1.24(0.57-2.72)$ & $0.79(0.39-1.60)$ & 0.049 \\
\hline Seed oil & 1.00 & $0.87(0.58-1.30)$ & $0.85(0.33-2.18)$ & $1.42(0.58-3.48)$ & 0.993 \\
\hline \multicolumn{6}{|c|}{ Fats for sauces } \\
\hline Butter & 1.00 & $1.03(0.80-1.31)$ & $1.79(1.02-3.13)$ & $2.36(1.05-5.30)$ & 0.047 \\
\hline Margarine & 1.00 & $1.08(0.72-1.63)$ & $1.14(0.78-1.67)$ & & 0.493 \\
\hline
\end{tabular}


Table 10. - Summary results of the association between fruit and vegetables and fats with respiratory symptoms

\begin{tabular}{|c|c|c|c|c|}
\hline \multirow[t]{2}{*}{ Foods/Food groups } & \multicolumn{4}{|c|}{ Symptoms } \\
\hline & Wheeze & Shortness of breath & Nocturnal cough & Chronic cough \\
\hline \multicolumn{5}{|l|}{ Fruit and vegetables } \\
\hline Cooked vegetables & $\begin{array}{c}0.67(0.41-1.09) \\
0.125\end{array}$ & $\begin{array}{c}0.72(0.41-1.25) \\
0.318\end{array}$ & $\begin{array}{c}0.61(0.45-0.83) \\
0.006\end{array}$ & $\begin{array}{c}0.62(0.42-0.89) \\
0.005\end{array}$ \\
\hline Summer tomatoes & $\begin{array}{c}0.49(0.31-0.80) \\
0.003\end{array}$ & $\begin{array}{c}0.55(0.32-0.96) \\
0.031\end{array}$ & $\begin{array}{c}0.67(0.50-0.90) \\
0.008\end{array}$ & $\begin{array}{c}0.55(0.40-0.77) \\
<0.001\end{array}$ \\
\hline Fresh fruits & $\begin{array}{c}0.51(0.24-1.11) \\
0.090\end{array}$ & $\begin{array}{c}0.37(0.16-0.85) \\
0.022\end{array}$ & $\begin{array}{c}0.37(0.22-0.61) \\
<0.001\end{array}$ & $\begin{array}{c}0.46(0.26-0.82) \\
0.021\end{array}$ \\
\hline Citrus fruits & $\begin{array}{c}0.93(0.58-1.49) \\
0.700\end{array}$ & $\begin{array}{c}0.59(0.35-1.00) \\
0.016\end{array}$ & $\begin{array}{c}0.67(0.49-0.93) \\
<0.001\end{array}$ & $\begin{array}{c}0.85(0.58-1.26) \\
0.035\end{array}$ \\
\hline \multicolumn{5}{|l|}{ Fats } \\
\hline Bread and butter & $\begin{array}{c}2.09(0.80-5.44) \\
0.143\end{array}$ & $\begin{array}{c}3.12(1.18-8.23) \\
0.106\end{array}$ & $\begin{array}{c}1.75(0.91-3.35) \\
0.164\end{array}$ & $\begin{array}{c}1.00(0.41-2.43) \\
0.502\end{array}$ \\
\hline Butter for cooking & $\begin{array}{c}2.19(0.90-5.30) \\
0.031\end{array}$ & $\begin{array}{c}1.52(0.50-4.60) \\
0.472\end{array}$ & $\begin{array}{c}1.16(0.61-2.24) \\
0.677\end{array}$ & $\begin{array}{c}0.85(0.39-1.88) \\
0.695\end{array}$ \\
\hline Bread and margarine & $\begin{array}{c}2.52(1.25-5.09) \\
0.024\end{array}$ & $\begin{array}{c}1.90(0.744 .89) \\
0.164\end{array}$ & $\begin{array}{c}1.81(1.07-3.06) \\
0.065\end{array}$ & $\begin{array}{c}1.62(0.89-2.97) \\
0.283\end{array}$ \\
\hline
\end{tabular}

Data are presented as odds ratio (OR) of the highest level of consumption versus never ( $95 \%$ confidence interval) and $\mathrm{p}$-value for trend. OR are adjusted for the following confounders: sex, study area, paternal education, maternal and paternal smoking, parental asthma, dampness or mould in the child's room, household crowding.

function again [26]. Vitamin E, of which olive oil is the principle source in Mediterranean diet, is a fat-soluble constituent of the cell membrane and represents the body's principal defence against oxidant-induced membrane injury, breaking the lipid peroxidation chain reaction. Vitamin E seems to suppress neutrophil migration [13], and inhibits immunoglobulin (Ig)E production [14].

Some evidence on the role of vegetables and fresh fruit on asthma-like symptoms have been found in children. Apart from the authors previous results [20], in a cross-sectional study in England and Wales [19], children who never ate fresh fruit had an forced expiratory volume in one second of $79 \mathrm{~mL}$ $(4.3 \%)$ lower than that of children who ate fruit more than once a day, and this association was even stronger in children with wheezing. A case-control study on childhood asthma in Saudi Arabia found a strong protective effect for vegetable consumption and Vitamin E intake [17]. An ecological analysis of the ISAAC study involving 53 countries (children aged 13-14 yrs) has shown a consistent pattern of a decrease in wheezing symptoms, allergic rhinoconjunctivitis, and atopic eczema associated with an increased per capita consumption of vegetables, vegetable nutrients, and nuts [27]. A recent study involving 20,000 children from central-eastern European countries has found a protective effect of fruit and vegetables consumption on the occurrence of cough and on wheezing symptoms and the effects were stronger when considering summer fruit and vegetables [28]. In adults, an increase in bronchial reactivity associated with lower intake of vitamin C was found [29], while BODNER et al. [30] found that a higher intake of vitamin $\mathrm{E}$ was related to a lower risk of asthma onset. The current study shows a protective effect for nuts on the prevalence of shortness of breath with wheeze, and a similar result was found in the Nurses' Health Study. Women participating in that study had lower incidence of asthma in the highest quintile of vitamin $\mathrm{E}$ intake, and the effect was attenuated after excluding nut consumption [31]. However, nuts not only contain vitamin $\mathrm{E}$ but also magnesium, which has been shown to protect against asthma among adults [15], though it should be noted that the association with nuts is based on relatively few subjects and might just be a spurious finding.

It is difficult to single out the most important antioxidant nutrient responsible for the protection, since the amount of vitamins $\mathrm{C}$ and $\mathrm{E}$, and carotenoids are highly correlated. However, of note is that among the types of vegetables and fruit investigated, the strongest result was the protective role of summer tomatoes. In the longitudinal Nurses' Health Study [31], consumption of tomato juice and tomato sauce was inversely related to asthma incidence. Moreover, a study regarding Sudanese children has linked tomato consumption with a reduction of respiratory infections [32]. Tomatoes contain lycopene, a carotenoid with a strong antioxidant property, and other potentially beneficial substances, including vitamin $\mathrm{C}$ and $\mathrm{E}$ [33]. High intake of tomatoes or lycopene has been associated with decreased cancer risk [34], in particular lung, stomach and prostate cancer. The results from the current study are a clear indication that more research is warranted on the potential beneficial effects of foods containing lycopene.

The current study shows a harmful effect of both margarine and butter consumption in relation to "any wheeze" and "shortness of breath with wheeze". Butter used for pasta was also correlated with allergic rhinitis. Margarine is rich in polyunsatured fatty acids, particularly omega- 6 fatty acid, while butter is an animal fat rich in saturated fatty acids. The Zutphen study revealed that high intake of PUFA and linoleic acid was associated with high incidence of chronic lung disease [35]. A recent ecological study regarding 37 centres in Europe showed a positive association between daily intake of monounsaturated (MUFA) fatty acid and prevalence of allergic sensitisation in adults [36], while the Nurses Health Study showed inverse association between the intake of MUFA and linoleic acid and asthma incidence [31]. Among preschool Australian children, the risk of asthma was higher for a high consumption of PUFA [21]. A cross-sectional study conducted in Germany found an association between margarine consumption, compared to butter use, and rhinitis symptoms. [37]. A possible explanation for these findings is that high intake of fats leads to an increased ratio of omega- 6 to omega-3 fatty acids. In general, PUFA have been shown to modify cell-mediated immunity, as well as IgE production and allergic responses [38], but omega-3 PUFA and omega-6 PUFA have different effects on inflammation. The omega-3 PUFA have a specific role in controlling inflammation, but are easily replaced by omega-6 PUFA, which exert the opposite activity. Atopic patients have an altered composition 
of PUFA in serum and cell membranes, while a balance between n-3 PUFA and n-6 PUFA metabolism exists in nonallergic children [39]. However, a complete explanation for the biological mechanism that involves PUFA on airway inflammation has not been found [40].

While PUFA have been relatively well studied, less attention has been paid to the role of saturated fats in inflammation. It has been suggested that saturated fats may modify serum cholesterol levels and the cell membrane content of arachidonic acid, both of which may affect lymphocyte function. However, how saturated fats may modify airway inflammation remains unknown [13]. From an epidemiological perspective, there are two observations on the role of saturated fats on asthma. Results from the First Nutrition and Health survey in Taiwan suggested an increase of the risk of asthma in teenagers corresponds to an increased intake of saturated fats, while MUFA fats were inversely related with asthma [13]. The case-control study of adults by BODNER et al. [30] found a protective effect of low saturated fat consumption.

The biological mechanism underlying the association between rhinitis symptoms and milk intake is difficult to explain. Although milk consumption has been considered as a proxy for vitamin A intake and lower prevalence of chronic bronchitis has been observed among subjects drinking milk daily versus never [41], a bias could have occurred. Symptomatic children may avoid milk because of food intolerance, since milk is one of the most allergenic foods [25], and the observed effect may be due only to such selective avoidance. However, the association between allergic rhinitis and nuts consumption is probably correct, since the allergenic properties of nuts are well known [25]. It is worthy of note that, like in the study conducted in Taiwan on the role of diet on asthma and allergic rhinitis [13], apart from butter used on pasta, none of the dietary factors that were associated with wheeze showed a significant association with allergic rhinitis. This finding suggests that dietary components act via an inflammatory mechanism, other than eosinophilic inflammation, to produce increased bronchial reactivity and reversible airways obstruction.

Several limitations of the study should be noted and caution needs to be taken in interpreting the results due to the following factors: 1) The authors have considered parental reports of children's diet and symptoms, and information bias could have occurred. Although questionnaire data on dietary items recorded by parents are considered to be accurate enough, especially regarding fruit and vegetable intake [42], the questionnaire was not validated against a standard. It is well known that brief food frequency questionnaires are useful to analyse the association between nutrient intake and chronic disease, but they are subject to substantial measurement error and dietary change [43]; 2) The analysis considers symptoms and diet collected at the same time; 3) Although the authors considered more foods and food groups than other studies, the scope of the nutrients that were investigated is limited and information of total energy intake is unavailable; 4) It is difficult to single out the specific factor when food patterns, rather than a specific food, may be associated with the outcomes. However, the authors did not find a high correlation among the dietary variables that were investigated; 4) When investigating protective effects, there is always the possibility of "reverse bias", namely that those with symptoms purposely avoid these foods; 5) Some analyses are based on few subjects and the results may be due to chance; 6) The authors do not have information on height and weight, possibly relevant variables for wheezing.

In conclusion, the current study has suggested a preventive role of a diet rich in vegetables and fruit and low in fatty foods on childhood wheeze. However, the role of diet in the development of childhood asthma, the relevant time windows (including during pregnancy) and induction time, and the biological mechanisms underlying the associations, all need to be further investigated before promoting a specific diet for primary and secondary asthma prevention.

\footnotetext{
Acknowledgements. The authors would like to thank P. Compagnucci and M. Huber for their help in editing the paper.
}

\section{References}

1. International Study on Asthma and Allergies in Childhood (ISAAC). Worldwide variation in prevalence of symptoms of asthma, allergic rhinoconjunctivitis, and atopic eczema: ISAAC. Lancet 1998; 351: 1225-1232.

2. Worldwide variations in the prevalence of asthma symptoms: the International Study of Asthma and Allergies in Childhood (ISAAC). Eur Respir $J$ 1998; 12: 315-335.

3. Beasley R, Crane J, Lai CK, Pearce N. Prevalence and etiology of asthma. J Allergy Clin Immunol 2000; 105: Suppl. 2, 466-472.

4. Italian Studies on Respiratory Disorders in Children and the Environment (SIDRIA). Asthma and respiratory symptoms in 6-7 year old Italian children: gender, latitude, urbanization and socio-economic factors. Eur Respir $J$ 1997; 10: $1780-1786$.

5. Burney PG. The causes of asthma- does salt potentiate bronchial activity? J R Soc Med 1987; 80: 364-367.

6. Seaton A, Godden DJ, Brown K. Increase in asthma: a more toxic environment or a more susceptible population? Thorax 1994; 49: 171-174

7. Weiland SK, von Mutius E, Husing A, Asher MI. Intake of trans fatty acids and prevalence of childhood asthma and allergies in Europe. ISAAC Steering Committee. Lancet 1999; 12: 2040-2041.

8. Hatch GE. Asthma, inhaled oxidants, and dietary antioxidants. Am J Clin Nutr 1995; 61: Suppl. 3, 625-630.

9. Black PN, Sharpe S. Dietary fat and asthma: is there a connection? Eur Respir J 1997; 10: 6-12.

10. Romieu I, Trenga C. Diet and obstructive lung diseases. Epidemiol Rev 2001; 23: 268-287.

11. Monteleone CA, Serman AR. Nutrition and asthma. Arch Intern Med 1997; 157: 23-34.

12. Heffner JE, Repine JE. Pulmonary strategies of antioxidant defence. Am Rev Resp Dis 1989; 140: 531-554.

13. Huang SL, Pan WH. Dietary fats and asthma in teenagers: analyses of the first Nutrition and Health Survey in Taiwan (NAHSIT). Clin Exp Allergy 2001; 31: 1875-1880.

14. Pistelli R, Forastiere F, Corbo GM, et al. Respiratory symptoms and bronchial responsiveness are related to dietary salt intake and urinary potassium excretion in male children. Eur Respir J 1993; 6: 517-522.

15. Britton J, Pavord I, Richards K, et al. Dietary magnesium, lung function, wheezing, and airway hyperreactivity in a random adult population sample. Lancet 1994; 6: 357-362.

16. Shaheen SO, Sterne JA, Thompson RL, Songhurst CE, Margetts BM, Burney PG. Dietary antioxidants and asthma in adults: population-based case-control study. Am J Respir Crit Care Med 2001; 164: 1823-1828.

17. Hijazi N, Abalkhail B, Seaton A. Diet and childhood asthma in a society in transition: a study in urban and rural Saudi Arabia. Thorax 2000; 55: 775-779.

18. Hodge L, Salome CM, Peat JK, Haby MM, Xuan W, Woolcock AJ. Consumption of oily fish and childhood asthma risk. Med J Aust 1996; 164: 137-140.

19. Cook DG, Carey I, Whincup PH, et al. Effect of fresh fruit 
consumption on lung function and wheeze in children Thorax 1997; 52: 283-288.

20. Forastiere F, Pistelli R, Sestini P, et al. Consumption of fresh fruit rich in vitamin $\mathrm{C}$ and wheezing symptoms in children. SIDRIA Collaborative Group, Italy (Italian Studies on Respiratory Disorders in Children and the Environment). Thorax 2000; 55: 283-288.

21. Haby MM, Peat JK, Marks GB, Woolcock AJ, Leeder SR. Asthma in preschool children: prevalence and risk factors. Thorax 2001; 56: 589-595.

22. Agabiti N, Mallone S, Forastiere F, et al. The impact of parental smoking on asthma and wheezing. SIDRIA Collaborative Group. Studi Italiani sui Disturbi Respiratori nell'Infanzia e 1'Ambiente. Epidemiology 1999; 10: 692-698.

23. Shi J, Le Maguer M. Lycopene in tomatoes: chemical and physical properties affected by food processing. Crit Rev Biotechnol 2000; 20: 293-334.

24. Takeoka GR, Dao L, Flessa S, et al. Processing effects on lycopene content and antioxidant activity of tomatoes. J Agric Food Chem 2001; 49: 3713-3717.

25. Baker JC, Ayres JG. Diet and asthma. Respir Med 2000; 94: 925-934.

26. Fogarty A, Britton J. The role of diet in the aetiology of asthma. Clin Exp Allergy 2000; 30: 615-627.

27. Ellwood P, Asher MI, Bjorksten B, et al. Diet and asthma, allergic rhinoconjunctivitis and atopic eczema symptoms prevalence: an ecological analysis of the International Study of Asthma and Allergies in Childhood (ISAAC) data. Eur Respir J 2001; 17: 436-443.

28. Antova T, Pattenden S, Nikiforov B, et al. Nutrition and respiratory health in children in six Central and Eastern European countries. Thorax 2003; 58: 231-236.

29. Soutar A, Seaton A, Brown K. Bronchial reactivity and dietary antioxidants. Thorax 1997; 52: 166-170.

30. Bodner C, Godden D, Brown K, Little J, Ross S, Seaton A. Antioxidant intake and adult-onset wheeze: a case-control study. Aberdeen WHEASE Study Group. Eur Respir J 1999; 13: $22-30$

31. Troisi RJ, Willett WC, Weiss ST, Trichopoulos D, Rosner B, Speizer FE. A prospective study of diet and adult-onset asthma. Am J Respir Crit Care Med 1995; 151: 1401-1408.
32. Fawzi W, Herrera MG, Nestel P. Tomato intake in relation to mortality and morbidity among sudanese children. $J$ Nutr 2000; 130: 2537-2542.

33. Beecher GR. Nutrient content of tomatoes and tomato products. Proc Soc Exp Biol Med 1998; 218: 98-100.

34. Giovannucci E. Tomatoes, tomato-based products, lycopene, and cancer: review of the epidemiologic literature. J Natl Cancer Inst 1999; 91: 317-331.

35. Miedema I, Feskens EJ, Heederik D, Kromhout D. Dietary determinants of long-term incidence of chronic nonspecific lung diseases. The Zutphen study. Am J Epidemiol 1993; 138: $37-45$.

36. Heinrich J, Holscher B, Bolte G, Winkler G. Allergic sensitization and diet: ecological analysis in selected European cities. Eur Respir J 2001; 17: 395-402.

37. Bolte G, Frye C, Hoelscher B, Meyer I, Wjst M, Heinrich J. Margarine consumption and allergy in children. Am J Respir Crit Care Med 2001; 163: 277-279.

38. Yamada K, Hung P, Yoshimura K, Taniguchi S, Lim B, Sugano M. Effect of unsatured fatty acids and antioxidants on immunoglobulin production by mesentric lymph node lymphocytes of Sprague-Dawley rats. J Biochem 1996; 120: 138-144.

39. Yu G, Bjorksten B. Polyunsatured fatty acids in school children in relation to allergy and serum IgE levels. Pediatr Allergy Immunol 1998; 9: 133-138.

40. Woods RK, Thien F. Polyunsaturated fats and asthma. Thorax 2002; 57: 94.

41. Tockman MS, Khoury MJ, Cohen BH. Milk drinking and possible protection of the respiratory epithelium. J Chronic Dis 1986; 39: 207-209.

42. Byers T, Trieber F, Gunter E, et al. The accuracy of parental reports of their children's intake of fruits and vegetables: validation of a food frequency questionnaire with serum levels of carotenoids and vitamins C, A, and E. Epidemiology 1993; 4: 350-355.

43. Xing X, Burr JA, Brasure JR, Neugut AI, Marshall JR. Reproducibility of nutrient intake in a food frequency questionnaire used in a general population. Nutr Cancer 1996; 25: 259-268. 